\title{
Numerical Taxonomy of Some Named Coryneform Bacteria
}

\author{
By G. H. G. DAVIS AND K. G. NEWTON \\ Department of Microbiology, University of Queensland, Brisbane, Australia
}

(Accepted for publication I6 January 1969)

SUMMAR Y

Numerical analysis of data for seventy coryneform bacteria bearing the following generic names, Mycobacterium, Nocardia, Jensenia, Listeria, Erysipelothrix, Kurthia, Brevibacterium, Arthrobacter, Cellulomonas, Microbacterium and Corynebacterium, was done by using 70 coded features and both single and complete linkage clustering programs.

Three major phenons were detected, probably corresponding taxonomically to the present family level in the taxonomic hierarchy. The first included Listeria, Kurthia, Erysipelothrix, certain Microbacterium strains and Corynebacterium species of animal origin. The second included rapid-growing Mycobacterium species, Nocardia and Jensenia. The third was a more illdefined group of Arthrobacter, Brevibacterium, Cellulomonas, Microbacterium and certain other species. We suggest that all three phenons belong in the order Eubacteriales under the possible family names of Corynebacteriaceae, Mycobacteriaceae and Arthrobacteriaceae respectively.

\section{INTRODUCTION}

Gram-positive bacteria are currently classified in five major groups. Four of these, the micrococci, sporing bacilli, lactic-acid bacteria and the coryneforms, are considered members of the order Eubacteriales, whilst overtly acid-fast coryneforms and the actinomycetes are placed in a separate order, Actinomycetales. The problems inherent in dividing Gram-positive bacteria into taxa at the generic, familial and ordinal level have been remarked by various workers and the reader is referred to Davis \& Freer (I960), Gordon (I966) and Jensen (I966) for material relevant to the coryneform problem in particular. Some of the difficulty stems from the fact that taxonomy of bacteria at the 'alpha' level is based on morphology and, as the name implies, coryneforms are irregular in this respect. More subtle problems are also encountered, however, such as gradation in acid-fastness (Harrington, I966) and the taxonomic interpretation of cell-wall analysis (Cummins, 1962) and nutritional needs (Keddie, Leask \& Grainger, I966). In attempting to classify bacteria, or anything else for that matter, we assume that natural discontinuities or groupings exist in the material studied and can be detected if looked for. As the amount of information upon which groupings may be made increases, the detection of groups becomes more difficult. Numerical taxonomy (Sokal \& Sneath, 1963) offers a practical means of reducing this difficulty by impartial mechanical data analysis.

The present study was an attempt to detect similarity groupings in 70 strains of 'coryneform' bacteria, all of which have been maintained for varying periods in this and other laboratories under the names shown in Table I. Eleven generic names occur in this list and the strains represent isolates from diverse habitats. An investigation of basically similar design was reported by Da Silva \& Holt in 1965. 
Table I. Strains examined

Study no.

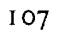

12

I 3

92

91

94

106

IO 4

93

14

108

105

109

15

16

66

69

70

71

134

5

8

9

76

77

$10 I$

I 32

I 35

137

140

173

I 79

180

I 94

217

200

237

34

208

209
Name on receipt

Brevibacterium superdae

B. linens

B. linens

B. insectiphilium

B. sociovivum

B. imperiale

B. imperiale

B. ammoniagenes

$B$. ammoniagenes

B. helvolum

$B$. protophormiae

B. fuscum

$B$. vitarumen

Mycobacterium hvalinum

M. phlei

$M$. fortuitum

$M$. rhodochrous

M. lacticola

M. lacticola

$M$. ranae

Nocardia salmonicolor

N. opaca

N. rubropertincra

$N$. coeliaca

N. rubra

N. corallina

$N$. salivae

$N$. asteroides

Nocardia sp.

Corynebacterium diphtheriae

C. renale

C. ovis

C. equi

C. ulcerans

C. murium

C. murium

C. xerosis

C. michiganense

Erysipelothrix insidiosa

E. insidiosa

Listeria monocytogenes

Microbacterium thermosphactum

M. lacticum

M. lacticum

Microbacterium sp.

Microbacterium sp.

Microbacterium sp.

Microbacterium sp.

Microbacterium sp.

Microbacterium sp.

Microbacterium sp.

Kurthia zopfii

K. zopfii

Jensenia canicruria

Arthrobacter terregens

A. terregens

A. tumescens

A. pascens
Donor*

Donor number

A

B

B

C

C

C

A

A

B

A

A

A

B

B

一

C

C

D

B

B

B

B

C
CCEB 366

CCEB 282

CCEB 277

CCEB 252

$$
\text { II } 19
$$$$
\text { I } 20
$$

NCTC 8573

NCTC 8I 39

OI I

Or 2

I 2 I

133

I 34

I 32

NOC 19

I 3 I

KARLSON

2650

NCTC 7448

NCTC $345^{\circ}$

NCTC I 62 I

48

NCTC 949

II 5

WU II 6

v 535

2682

268 I

SULZBACHER SW 26

275

IOI

9

IO

I I

I 5

22

27

I 19

92

93

6

NCIB 8909 
Table I (cont.)

Study no.

20
240
$24 I$
244
21
22
238
239
24
23
96
II

Name on receipt
A. simplex
A. simplex
A. citreus
A. citreus
A. citreus
A. globiformis
A. globiformis
A. globiformis
A. ureafaciens
A. aurescens
Cellulomonas favigena
C. biazotea

Donor *
B
I
I
I
B
B
I
I
B
B
-

Donor number

$$
\begin{array}{r|r}
5 \\
\text { NCIB } & 8929 \\
\text { NCIB } 8908 \\
\text { WU } 484 \\
2 \\
3 \\
\text { WU } 477 \\
\text { NCIB } 8907 \\
8 \\
1 \\
\text { NCIB } 8073 \\
\text { NCIB } 8077
\end{array}
$$

* Donors. A, O. Lysenko, Czechoslovak Acad. Sci., Prague; B, E. Szabo, Microbiology Culture Collection, University of Queensland; C, J. V. Bhat, Indian Inst. of Science, Bangalore; D, M. R. McLean, CSR, Roseville, N.S.W.; E, R. Harris, Inst. of Dental Research, Sydney; F, E. F. Crowder, Inst. of Medical and Veterinary Science, Adelaide; G, R. W. Cobb, I.C.I. Research Division, Macclesfield; H, J. C. Keast, Veterinary Research Station, Glenfield, N.S.W.; I, C. A. Parker, Inst. of Agriculture of West Australia, Nedlands; J, R. F. Jones, Dept. of Veterinary Pathology, University of Sydney, N.S.W.; k, G. Simmonds, Animal Research Institute, Brisbane; L, L. Brownlie, C.S.I.R.O. Meat Preservation Laboratory, Brisbane.

\section{METHODS}

(a) Strains studied. These are listed in Table I. In view of the possibility of misrepresentation we wish to point out that none of the strains bearing internationally recognized culture collection labels was obtained direct from those collections.

(b) Strain growth and maintenance. Initial examination of all strains for purity by multiple subculture on solid media was routinely done. All grew aerobically at $28^{\circ}$ on the following medium, subsequently referred to as P.Y.E. medium: peptone, $\mathrm{I} \%(\mathrm{w} / \mathrm{v})$, yeast extract, $0.5 \%(\mathrm{w} / \mathrm{v}), \mathrm{NaCl}, 0.5 \%(\mathrm{w} / \mathrm{v})$; for solid media $\mathrm{I} \cdot 5 \%(\mathrm{w} / \mathrm{v})$ Oxoid Agar No. 3 was added. During the test period strains were stored at $4^{\circ}$ on P.Y.E. slopes. Inocula for tests were grown from these in P.Y.E. broth incubated at $28^{\circ}$. All strains were lyophilized for long-term storage.

(c) Data collection. Unless otherwise indicated all characters were determined at $28^{\circ}$ on P.Y.E. medium or with P.Y.E. medium as the nutrient base. All other procedures and timings were standardized to enable direct strain-to-strain comparison. In the following brief descriptions the numbers in parentheses indicate the number of features coded from an observed character.

Forty-eight-hour discrete colonies were observed for colony diameter as under I $\mathrm{mm}$. or over $2 \mathrm{~mm}$. (2); margin entire or irregular (I); surface smooth or otherwise (I); elevation convex or flat (I) ; consistency butyrous, friable or solid (3). Cell morphology determined by Gram-stained smears (Jensen's modification; Cruickshank, I965), as rods present (I); regular rods (I); irregular rods (I); cocci (I); branching (I). Gram reaction (I). Acid-fast cells present (I) using $20 \%(\mathrm{v} / \mathrm{v})$ sulphuric acid for $3 \mathrm{~min}$. as decolorising agent. Catalase activity (I) by adding ' $\mathrm{I} O \mathrm{O}$ vol.' $\mathrm{H}_{2} \mathrm{O}_{2}$ to growth smeared on a clean slide. Oxidase reaction (I) by Kovacs' (1956) method.

Duplicate plate cultures incubated in the light and dark were observed at $48 \mathrm{hr}$ for pigmentation in the light, present (I); pink (I); yellow/red (I); yellow/green (I). Dark- 
incubated plates were exposed to light for I hr, re-incubated in darkness for $24 \mathrm{hr}$ and observed for photochromogenesis (I), i.e. appearance or enhancement of colour.

Growth in the absence of oxygen (I); at $37^{\circ}(\mathrm{I})$; on Hoyle medium (Cruickshank, I965) (I); on MacConkey agar (Oxoid CM5 broth plus $\mathrm{r} \cdot 5 \%$ (w/v) agar) (I); on Levine E.M.B. agar (Oxoid CM69) (I); all recorded after $48 \mathrm{hr}$.

Sensitivity to penicillin, I5 I.U. (I), streptomycin, $10 \mu \mathrm{g}$. (I), tetracycline, Io $\mu \mathrm{g}$. (I), chloramphenicol, Io $\mu \mathrm{g}$. (I), novobiocin, $5 \mu \mathrm{g}$. (I), oleandomycin, $5 \mu \mathrm{g}$ (I), erythromycin, Io $\mu \mathrm{g}$. (I) was determined after $48 \mathrm{hr}$ with Oxoid Multodisk no. II-I $4 \mathrm{C}$.

Growth at $5^{\circ}$ (I) was determined on plates incubated for 28 days.

Oxidation or fermentation of glucose (2) was tested by using Baird-Parker (I963) base with $\mathrm{I} \%(\mathrm{w} / \mathrm{v})$ glucose, $0.003 \%(\mathrm{w} / \mathrm{v})$ bromcresol purple and $\mathrm{I} \cdot 5 \%(\mathrm{w} / \mathrm{v})$ agar by Mossel's (I962) single tube method. Acetoin production (I) was detected by Barritt's method (Cruickshank, I965) after 6 days in P.Y.E. broth plus $I \%(w / v)$ glucose. Final pH below $5^{\circ} \circ$ (I) was recorded at 6 days in the acetoin tests above.

The neutral red test (I) of Cann \& Wilcox (I965) was modified to use P.Y.E. agar and read at 6 days. Clearing of $5 \%(\mathrm{v} / \mathrm{v})$ horse blood agar (I) was read at $48 \mathrm{hr}$. Citrate utilization (I) using Simmons' method, and aldehyde formation from glycerol (I) using Stern's method, were read after I4 days (Cruickshank, 1965). Hydrolysis of salicylate (1) (Tsukamura, I966) and cellulose (1) (Skerman, 1967) were observed for 4 weeks. Hydrolysis of tributyrin (I) (Willis, I960); Tweens 20, 40, 60 and 80 (4) (Sierra, I957); gelatin (I) (Frazier, I926); casein (I) (Davis \& Park, I962); starch (I) (Davis \& Park, 1962); DNA (I) (Jeffries, Holtman \& Guse, 1957, using Difco DNA-ase test agar) were read after 6 days. Hydrolysis of xanthine and tyrosine (2) (Gordon \& Smith, 1955) observed after I4 days. Liquefaction of Loeffler serum slopes (I) after 3 weeks.

Aesculin hydrolysis (I), method of Davis (I955) using P.Y.E. base; arbutin hydrolysis (I) as for aesculin, both read at 14 days. Hippurate hydrolysis (I) (Davis, I955) read at 6 days. Ammonia from arginine (I) (Davis, I955) read at 6 days. Thornley's (I960) arginine test (I) was modified to use P.Y.E. base and read at 6 days. Nitrate and nitrite reduction (2) were tested separately as recommended by ZoBell (1932) after 6 days. Indole production (v) was tested for in P.Y.E. broth plus $I \%(w / v)$ Oxoid acid-hydrolysed casein after 6 days by using the Ehrlich-Bohme reagent. Urease (I) was detected in a modified Christensen test (Cruickshank, 1965) at 6 days. A modified gluconate test (I) (Cruickshank, I965) was read at 6 days.

Diffusible brown pigment on P.Y.E. agar plus $0 . \mathrm{I} \%(\mathrm{w} / \mathrm{v})$ sterile catechol and in the tyrosine test referred to above was recorded at 6 and I4 days respectively (2).

Motility (I) was observed in hanging drop preparations of $48 \mathrm{hr}$ P.Y.E. broth cultures.

A total of 70 features were coded.

(d) Data analysis. The simple matching coefficient of Sokal \& Sneath (1963) was used for similarity assessment. Two clustering programs were tested, one relying on single linkage analysis and the other on complete (or multiple) linkage. The two programs were prepared by Miss E. Szabo of this department (to be published) and run on a GE 225 computer. The complete linkage analysis was stopped at the $60 \% \mathrm{~S}$ level after $2 \mathrm{I} \mathrm{min.} \mathrm{on} \mathrm{the} \mathrm{computes:.} \mathrm{The} \mathrm{single} \mathrm{linkage} \mathrm{analysis} \mathrm{took} 7 \mathrm{~min}$. of computer time and ran to completion. 


\section{RESULTS}

Several strains showed colonial variation during preliminary culture and were separated into discrete cultures. Three examples of this (strains 6I A and B, 63 A and B, $92 \mathrm{~A}$ and $\mathrm{B}$ ) were included in the study, bringing the total strains studied to 73 . Our

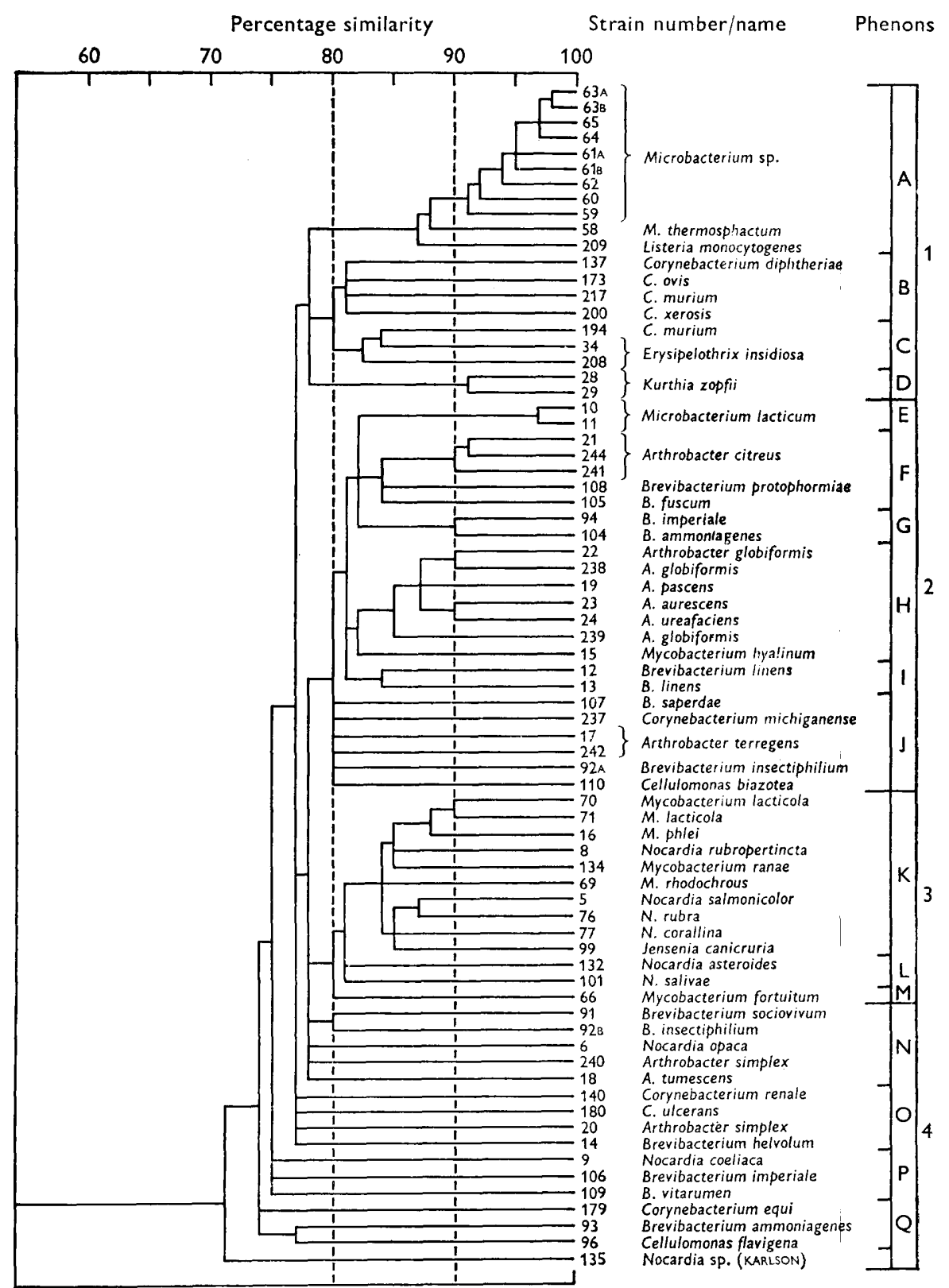

Fig. I. Dendrogram derived from single linkage analysis. 
results indicate that in the case of strains $6 \mathrm{I}$ and 63 the cultures separated were essentially the same but in the case of 92 the two cultures differed considerably and neither appeared to fit the description of Brevibacterium insectiphilium. Similar deviations from published descriptions were found in a number of the strains studied, e.g. strains 109 and 106 were both Gram-negative and motile. Most of the characters

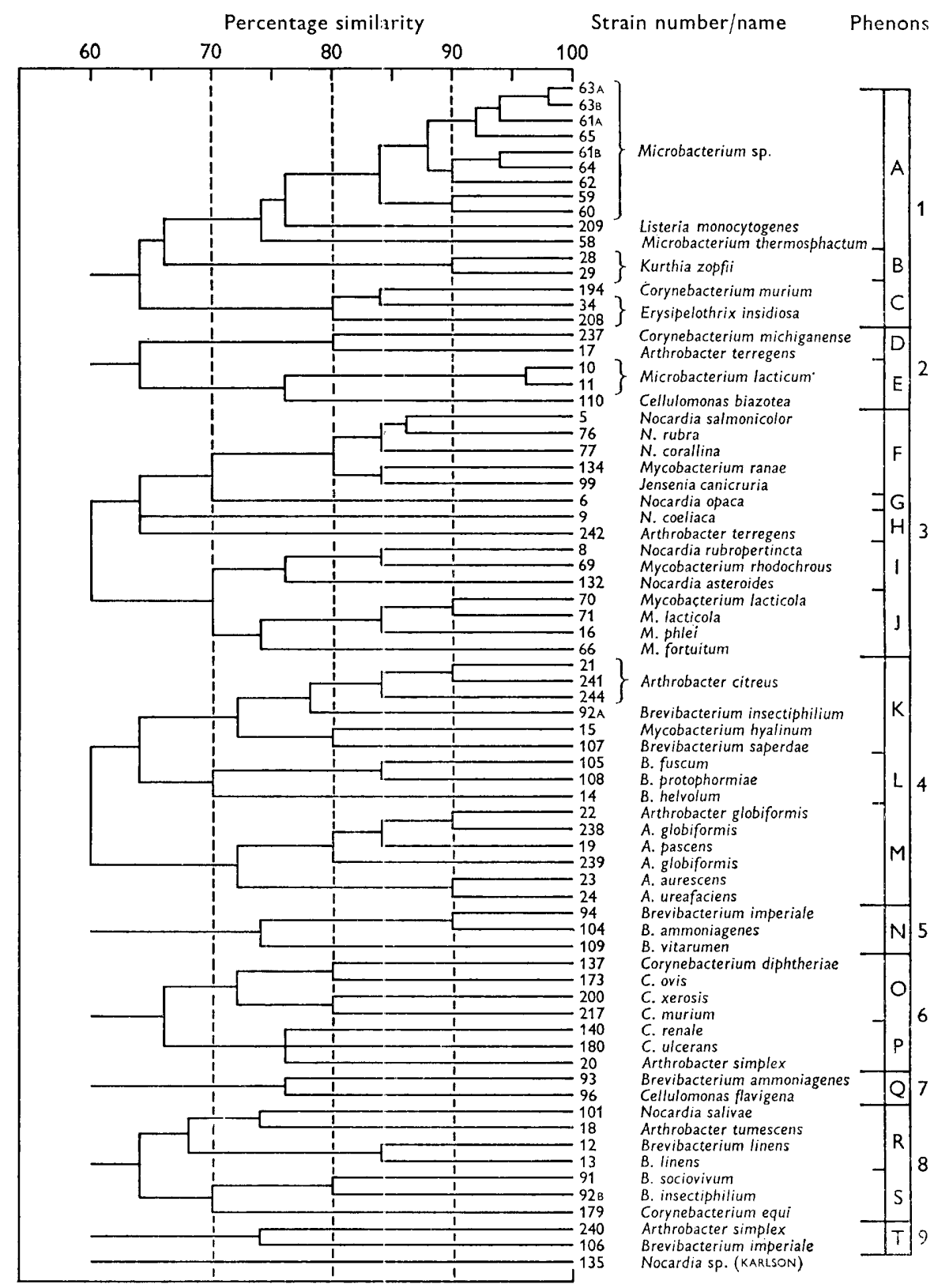

Fig. 2. Dendrogram derived from complete linkage analysis. 
recorded in this study have either been tested for in a non-comparable manner or not tested for at all in previous reports. Our objective was not identification but taxonomy and we have used the results obtained without prejudice.

Dendrograms based on the computer outputs using single and complete linkage

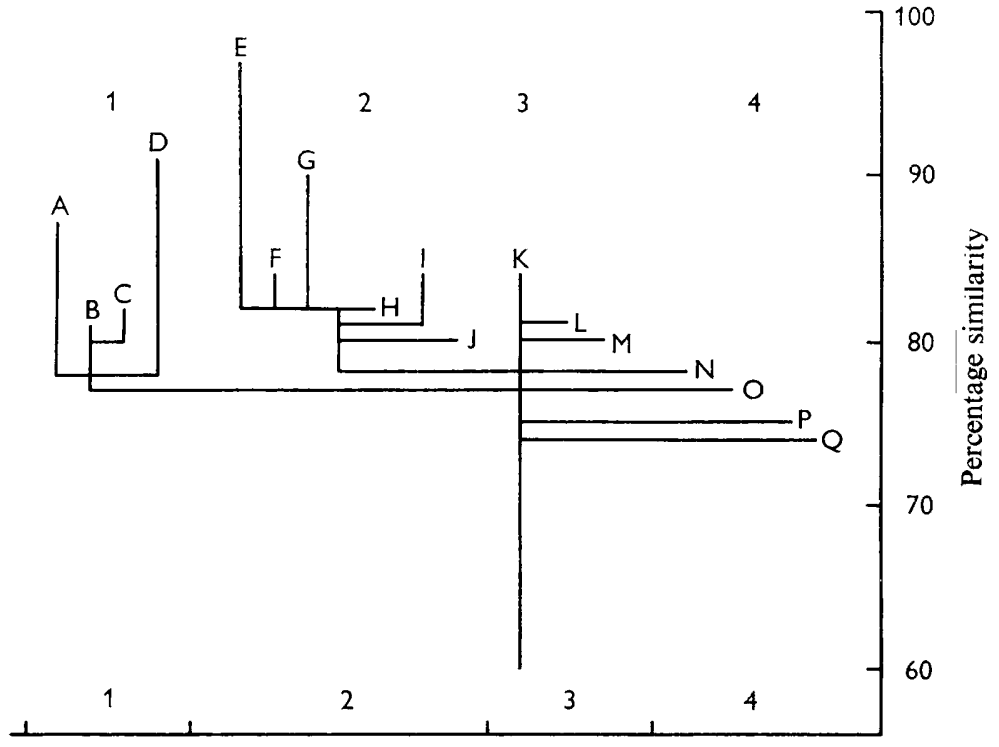

Phenons

Fig. 3. Schematic representation of single linkage clustering.

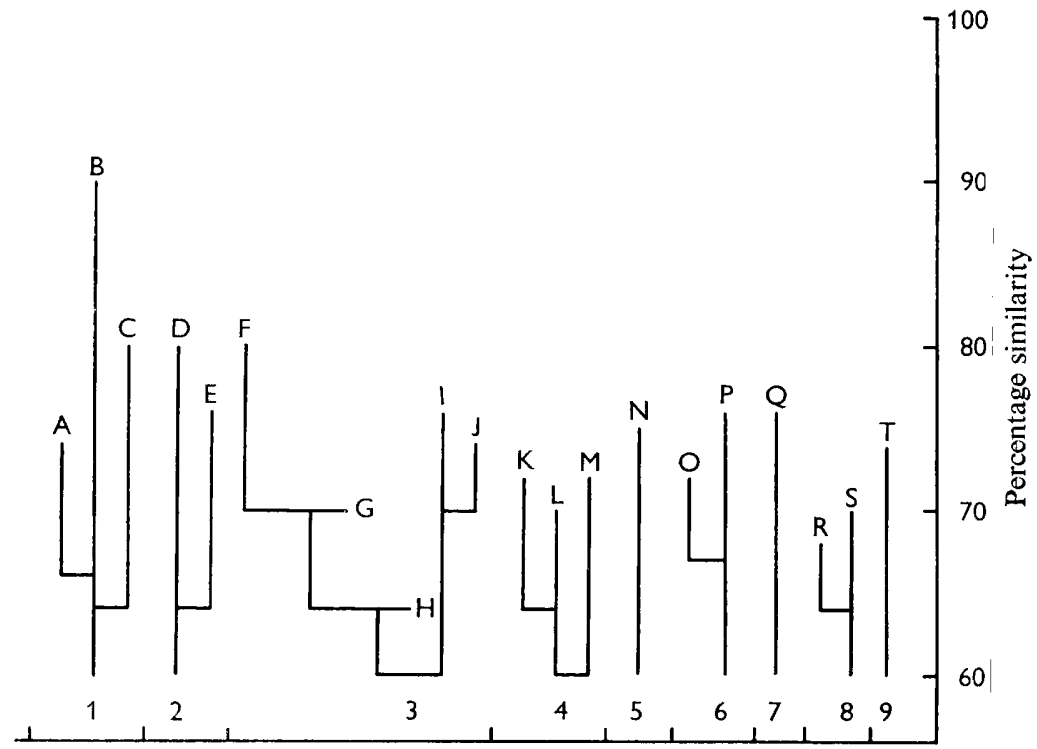

Phenons

Fig. 4. Schematic representation of complete linkage clustering. 
clustering programs are compared in Figs. I and 2. Figures 3 and 4 show these in simplified forms. The unsorted sirnilarity matrix for all the strains with the $S$ values shown as percentages is given in Fig. 5.

The numbers of clusters (phenons) formed and the numbers of strains clustered by the two methods at descending levels of similarity are shown in Table 2.

The complete linkage analysis to the $60 \% S$ level resulted in an incomplete sort and in comparison with the single linkage analysis led to differences in cluster (phenon) formation, particularly at lower $S$ levels. One strain, Nocardia sp. (KARLSON) I35, stood out from the rest of the strains in both analyses. The single linkage analysis indicated three large clusters at $c .80 \% S$ covering 57 of the 73 strains. Thirteen subclusters were indicated in these strains (A-M in Figs. $I$ and 3 ). By complete linkage three large clusters were formed at the $60-65 \% S$ level (I, 3 and 4 in Figs. 2 and 4), accounting for 46 strains and subdivisible into I I subclusters (A-C, F-J, K-M in Figs. 2 and 4). Groups 6 and 8 in Figs. 2 and 4 included seven strains each, divisible in each case into two subclusters.

Table 2. Comparison of strain clustering and phenon formation levels in single and complete linkage analyses

$\begin{array}{ccccc}S(\%) & \overbrace{\begin{array}{c}\text { No. of } \\ \text { phenons }\end{array}}^{\text {Single linkage }} & \begin{array}{c}\text { No. of } \\ \text { strains }\end{array} & \overbrace{\begin{array}{c}\text { No. of } \\ \text { phenons }\end{array}}^{\text {Complete linkage }} & \begin{array}{c}\text { No. of } \\ \text { strains }\end{array} \\ 95 & 2 & 8 & 2 & 4 \\ 90 & 8 & 24 & 10 & 23 \\ 85 & 8 & 35 & 10 & 25 \\ 80 & 6 & 59 & 18 & 5 \text { I } \\ 75 & 2 & 69 & 19 & 60 \\ 70 & \text { I } & 73 & 18 & 70 \\ 65 & - & - & 15 & 72 \\ 60 & - & - & 9 & 72\end{array}$

Similarities between the two cluster analyses were as follows: Nine strains labelled Microbacterium sp. clustered with one named Microbacterium thermosphactum (McLean \& Sulzbacher, I953) and the single strain of Listeria monocytogenes (Cluster I A in both analyses). Two strains of Microbacterium lacticum were well separated from this cluster and in both analyses they fell into the same major group as a strain of Corynebacterium michiganense and one of Cellulomonas biazotea. Two strains of Erysipelothrix clustered with one labelled Corynebacterium murium (I94). They eventually linked with the Microbacterium/Listeria and the Kurthia subclusters in both analyses. A second strain of Corynebacterium murium (217) clustered with three other corynebacteria of animal origin (xerosis, ovis, diphtheriae) in both analyses.

Cluster 3 in both analyses represented a clear group of Mycobacterium and Nocardia species although the exact composition and subclustering varied. Jensenia canicruria was included in this group.

Three strains of Arthrobacter citreus showed close similarity as also did three strains of $A$. globiformis; $A$. pascens (19), A. ureafaciens (23) and A. aurescens (24) were linked to the latter strains.

One strain of Arthrobacter simplex (20) showed relationship to Corynebacterium renale and C. ulcerans, which clustered together. Corynebacterium equi (179) was well separated from other corynebacteria. 


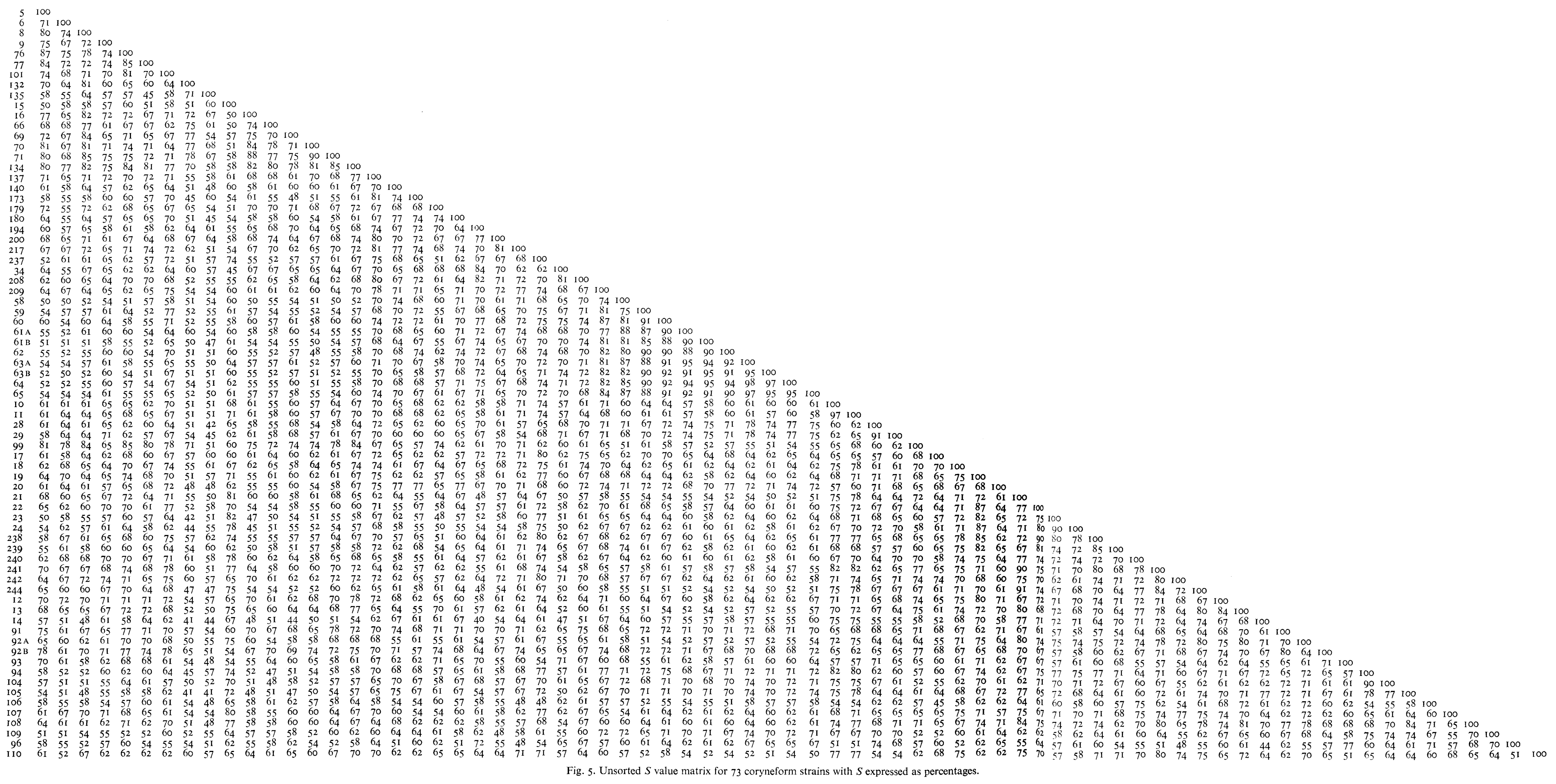


Cellulomonas flavigena (96) associated with a strain of Brevibacterium ammoniagenes (93); Cellulomonas biazotea (I Io) was well separated. A second strain of B. ammoniagenes (104) linked with a strain of $B$. imperiale (94) which in turn was well separated from the second $B$. imperiale strain (106). The two strains of $B$. linens clustered together. Brevibacterium fuscum (105) and $B$. protophormiae (I08) were linked and clustered with the $A$. citreus and $A$. globiformis strains; B. saperdae (107) and Mycobacterium hyalinum (15) fell into the same cluster.

Differences noticeable in the two cluster analyses were the separation of the animal corynebacteria from cluster $I$ in the multiple linkage analysis; the breakdown and redistribution of single linkage cluster 2 in the multiple linkage analysis and a similar redistribution of the poorly clustered strains in the lower part of Fig. I by the more searching analysis.

\section{DISCUSSION}

Apart from the absence of 'sugar fermentation' tests the characters used in this study resemble in general terms those commonly used in recently published papers on bacterial taxonomy by numerical analysis, e.g. Goodfellow (1967); Splittstoesser, Wexler, White \& Colwell (1967). Photochromogenesis is a characteristic used in Runyon's diagnostic scheme for anonymous mycobacteria (Runyon, 1955), and depends upon adaptive carotenoid production. It is a factor which needs to be considered in assessing cultures for pigment formation in taxonomic work. The following strains showed this character, Nocardia rubropertincta and Nocardia sp. (KARLSON), Mycobacterium hyalinum and $M$. rhodochrous, Brevibacterium aurescens, $B$. ureafaciens, B. insectiphilium (92 A) and B. saperdae. Except for Nocardia sp. (KARLSON) these strains clustered in two separate positions, some in the Nocardia/Mycobacterium cluster and some (including $M$. hyalinum) in the Arthrobacter globiformis/citreus cluster. Photo-induced carotenogenesis was discussed by Burchard \& Dworkin (1966) and Mathews (I966).

The Mycobacterium/Nocardia cluster of strains is well defined in our results and there is little evidence of linkage between this group and any of the corynebacteria examined. This reinforces Gordon's (1966) conclusion that the genus Corynebacterium is not a suitable repository for her Mycobacterium rhodochrous. Although there is good evidence against the present division of Corynebacterium, Mycobacterium and Nocardia at the ordinal level we cannot support Harrington's (1966) plea for a common genus. Recent studies on Mycobacterium taxonomy by Tsukamura (I966) and Bogdanescu \& Racotta (1967) did not cover the problems raised by Gordon's 1966 work although Tsukamura's separation of the rapidly growing and slowly growing species into two groups suggests that it may be possible to recognize a separate taxon composed of rapidly growing mycobacteria and related forms. This would include Gordon's Mycobacterium rhodochrous group and resemble the Mycobacterium/ Nocardia group detected in the present study. In view of the fact that the type species of Nocardia, N. asteroides, would probably be included it seems reasonable to suggest that the generic name Nocardia be retained for this taxon in spite of Gordon's desire to restrict it to strains capable of aerial mycelium formation. Such a taxon would clearly be heterogeneous in certain characters, particularly morphology, but others (e.g. DNA base ratios, Hill, 1966, and lipid analysis, Lanéele, Asselineau \& Castelnuovo, 1965) would probably uphold it, particularly if strains of Streptomyces 
currently masquerading as nocardias were eliminated. Corynebacterium equi (NCTC I62I), which was included by Cordon in an atypical $M$. rhodochrous group and clustered with mycobacteria in Harrington's work, was not well clustered in the present study. Our strains of Nocardia opaca, N. salivae (Davis \& Freer, I960, renamed Rothia dentocariosus by Georg \& Brown, 1967) and $N$. coeliaca were also imperfectly clustered in one or cther of the two programs used. Current evidence for the grouping of Corynebacterium species into sub-generic taxa is conflicting. Apart from the probable exclusion of $C$. haemolyticum and $C$. pyogenes (Cummins \& Harris, 1956) and a possible division into animal and plant corynebacteria (Da Silva \& Holt, 1965) opinions differ on what should be done with the present system (see Harrington, 1966, and Lazar, 1968). Our results support the recognition of a taxon for the animal corynebacteria (Fig. 2, Group 6) and although only one plant corynebacterium ( $C$. michiganense) was used the resulting clusters support Da Silva \& Holt's grouping of this bacterium with strains labelled Microbacterium lacticum (Fig. 2, Group 2; Fig. I, Group 2) and their separation from the $C$. diphtheriae group.

Recent studies of Microbacterium taxonomy by Robinson (1966 a,b) did not include strains of the organism named Microbacterium thermosphactum by McLean \& Sulzbacher (1953). Robinson recognized the three species $M$. flavum, $M$. lacticum and $M$. liquefaciens but recommended that the first of these be reallocated to the genus Corynebacterium on cell-wall and other evidence. He also noted close relationship between $M$. lacticum and $M$. liquefaciens. In our work two strains of $M$. lacticum associated in both cluster analyses with strains labelled Corynebacterium michiganense, Arthrobacter terregens and Cellulomonas biazotea. In Fig. I these bacteria fall into the large cluster including Arthrobacter globiformis and A. citreus. Keddie et al. (1966) could not classify a strain of $M$. lacticum with Arthrobacter, Corynebacterium or Cellulomonas on the basis of cell-wall composition but examination of their and other results suggests that the species shows cell-wall similarities with Arthrobacter terregens and $A$. flavescens, and inclusion in the Arthrobacter group in the present study is not unreasonable.

As pointed out by Barlow \& Kitchell (1966), the systematic position of Microbacterium thermosphactum is uneasy. It is more similar in certain respects to the lactobacilli than the coryneform microbacteria. The nine strains labelled 'Microbacterium sp.' in this work were obtained in the study reported by Weidemann (I965) from beef stored in nitrogen at $0^{\circ}$. They clustered well with a strain of $M$. thermosphactum and one of Listeria monocytogenes (Group IA, Figs. I and 2). Relationship with certain animal corynebacteria, Kurthia and Erysipelothrix is also indicated. This group (I in Figs. I and 2) differs from the other large clusters in Fig. I and all except Group 6 in Fig. 2 in being largely composed of non-pigmented, regular rods, showing anaerobic glucose metabolism, no reduction of nitrate and with no acid-fast members. The inclusion in this group of representative strains of four generic type species suggests that the subclusters discernible within Group I in Figs. I and 2 correspond to current genera. With the possible exception of the animal corynebacteria, most of these bacteria would probably be better: accommodated with the lactic-acid bacteria than the coryneforms.

Brevibacterium is acknowledged to be a taxon of convenience erected by Breed in 1953. Its heterogeneity is confirmed by the distribution of strains so named in Figs. I and 2. Da Silva \& Holt (I965) recommend that the type species $B$. linens be reallocated 
as Arthrobacter linens. Such a move would invalidate the present genus. In our results B. linens clustered closely with Arthrobacter globiformis upon single linkage analysis but was separated from the $A$. citreus/globiformis group by complete linkage analysis. In the latter analysis three possibly related groups of Brevibacterium strains occur, in Groups 4, 5 and 8. In Group 4, five Brevibacterium strains associate with the $A$. citreus/globiformis cluster. In Group 8, four strains cluster with $A$. tumescens. No association with the arthrobacters is seen in Group 5. These results suggest, however, that it may be possible to re-allocate most of the strains currently named Brevibacterium in generic taxa emerging from the Arthrobacter complex. Goodfellow (1967) found that his own results agreed with previous evidence for the separation of $A$. simplex and $A$. tumescens from a group of arthrobacters associated with $A$. globiformis. This subdivision is supported by our results, $A$. simplex and tumescens being separated in

Table 3. Percentage incidence of potentially diagnostic characters in the three major groups discernible by single linkage clustering ( 57 strains)

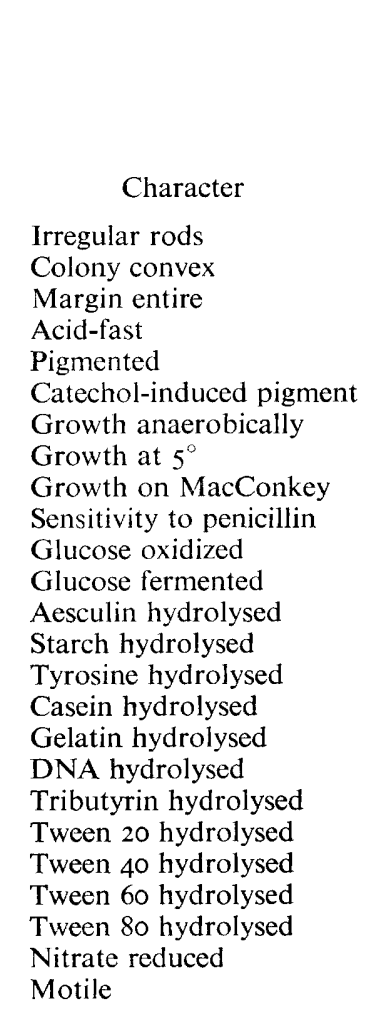

\begin{tabular}{|c|c|c|}
\hline $\begin{array}{l}\text { C. diph- } \\
\text { theriael } \\
\text { Listeria } \\
\text { group } \\
\text { (20 strains) }\end{array}$ & $\begin{array}{c}\text { Arthro- } \\
\text { bacter } \\
\text { Brevi- } \\
\text { bacterium } \\
\text { group } \\
\text { (24 strains) }\end{array}$ & $\begin{array}{c}\text { Myco- } \\
\text { bacterium/ } \\
\text { Nocardia } \\
\text { group } \\
\text { (13 strains) }\end{array}$ \\
\hline 20 & 90 & 100 \\
\hline 40 & 96 & 80 \\
\hline 20 & 100 & 33 \\
\hline 0 & 0 & 72 \\
\hline 0 & 75 & 88 \\
\hline 5 & 67 & 0 \\
\hline 90 & 42 & I 6 \\
\hline 45 & 90 & 8 \\
\hline 75 & 96 & 64 \\
\hline 95 & 90 & 40 \\
\hline I5 & 75 & 88 \\
\hline 65 & 20 & 0 \\
\hline 60 & 80 & 24 \\
\hline 20 & 80 & 0 \\
\hline 0 & 80 & 32 \\
\hline 5 & 84 & 0 \\
\hline 5 & 84 & 8 \\
\hline 5 & 71 & 0 \\
\hline 60 & 42 & 100 \\
\hline 30 & 62 & 88 \\
\hline 15 & 67 & 100 \\
\hline 15 & 62 & 100 \\
\hline I 5 & 25 & 100 \\
\hline 10 & 54 & 100 \\
\hline 20 & 33 & 0 \\
\hline
\end{tabular}

both analyses from the main group of arthrobacters (cf. Cummins \& Harris, 1959). If, as seems likely, the genus Brevibacterium is dispersed in reclassification of the arthrobacters, the family Brevibacteriaceae will lose its type genus and its validity in nomenclature. Our results indicate that Kurthia zopfii may represent a valid taxon related to the Listeria/Erysipelothrix/Microbacterium thermosphactum complex, with probable relationship also to animal corynebacteria. The displacement of Kurthia 
from the present family Brevibacteriaceae and inclusion at family level (Corynebacteriaceae?) with the above genera would not be unreasonable.

In conclusion we suggest that the present exploratory study indicates the existence of three major phenons in the strains studied. These are:

(a) Animal corynebacteria and other bacteria showing metabolic and other characters of possible relationship to the family Lactobacillaceae (Group I, Fig. I ; Groups I and 6, Fig. 2).

(b) Rapid-growing mycobacteria and Nocardia sp.; Family Mycobacteriaceae Order Eubacteriales. (Group 3 in Figs. I and 2.)

(c) Arthrobacter complex, requiring new family affiliation (Arthrobacteriaceae?) (Groups 2 and 4 (?), Fig. I; Groups 2, 4, 5, 7, 8 and 9, Fig. 2.)

The two Tables 3 and 4 have been included in an attempt to show the over-all characters of these three phenons based only on features that showed uneven distribution_among the three groups.

Table 4. Percentage incidence of potentially diagnostic characters in the three major groups discernible by complete linkage clustering (70 strains)

\begin{tabular}{|c|c|c|c|}
\hline Character & $\begin{array}{c}\text { C. diph- } \\
\text { theriael } \\
\text { Listeria } \\
\text { group } \\
\text { (23 strains) }\end{array}$ & $\begin{array}{c}\text { Arthro- } \\
\text { bacter } \\
\text { Brevi- } \\
\text { bacteria } \\
\text { group } \\
\text { (32 strains) }\end{array}$ & $\begin{array}{c}\text { Myco- } \\
\text { bacterium/ } \\
\text { Nocardia } \\
\text { group } \\
\text { (I5 strains) }\end{array}$ \\
\hline Regular rods & 64 & 27 & 33 \\
\hline Irregular rods & 17 & 72 & 92 \\
\hline Colonies convex & 39 & 84 & 80 \\
\hline Acid-fast & 0 & 0 & 60 \\
\hline Pigmented & 4 & 68 & 86 \\
\hline Growth anaerobically & 90 & 59 & 13 \\
\hline Growth at $37^{\circ}$ & $5 \mathrm{I}$ & 84 & 86 \\
\hline Growth at $5^{\circ}$ & 59 & 77 & 26 \\
\hline Growth on MacConkey & 77 & 96 & 53 \\
\hline Growth on EMB & 0 & 53 & 26 \\
\hline Sensitive to penicillin & 94 & $7 I$ & 33 \\
\hline Growth on Hoyle & 30 & 22 & 80 \\
\hline Glucose oxidized & 2 I & 65 & 86 \\
\hline Glucose fermented & 64 & 27 & 0 \\
\hline Acetoin produced & 69 & 34 & 0 \\
\hline Aesculin hydrolysed & $5 I$ & $7 \mathrm{I}$ & 24 \\
\hline Starch hydrolysed & 17 & 62 & 0 \\
\hline Tyrosine hydrolysed & 0 & 71 & 33 \\
\hline Casein hydrolysed & 17 & 71 & 0 \\
\hline Gelatin hydrolysed & 17 & 84 & 0 \\
\hline DNA hydrolysed & 4 & 62 & 0 \\
\hline Tributyrin hydrolysed & 60 & 46 & 92 \\
\hline Tween 20 hydrolysed & 43 & 56 & 86 \\
\hline Tween 40 hydrolysed & 17 & 71 & 100 \\
\hline Tween 60 hydrolysed & 17 & 62 & 100 \\
\hline Tween 80 hydrolysed & $2 x$ & 27 & 92 \\
\hline Oxidase & 9 & 62 & 7 \\
\hline Nitrate reduced & I3 & 62 & 86 \\
\hline Motile & 17 & 28 & 13 \\
\hline
\end{tabular}

The authors thank Miss A. Buckridge for technical assistance and all those who donated strains used in this study. 


\section{REFERENCES}

Batrd-PARKer, A. C. (1963). A classification of micrococci and staphylococci based on physiological and biochemical tests. J. gen. Microbiol. 30, 409.

Barlow, J. \& Kitchell, A. G. (I966). A note on the spoilage of prepacked lamb chops by Microbacterium thermosphactum. J. appl. Bact. 29, 185.

BOGDANESCU, V. \& RACOTTA, R. (1967). Identification of Mycobacteria by overall similarity analysis. J. gen. Microbiol. 48, II I.

BREED, R. S. (1953). The Brevibacteriaceae fam. nov. of order Eubacteriales. VI. Congresso Internazionale di Microbiologia $\mathbf{1}, 13$.

BURChARD, R. P. \& DWORKIN, M. (1966). Light-induced lysis and carotenogenesis in Myxococcus xanthus. J. Bact. 9I, 535.

CANN, D. C. \& WILcox, M. E. (1965). Analysis of multimolecular enzymes as an aid to the identification of certain rapidly growing mycobacteria using starch gel electrophoresis. J. appl. Bact. 28, 165.

CRUICKSHANK, R. (1965). Medical Microbiology. I th Ed. Edinburgh: Livingstone.

Cummins, C. S. (1962). Chemical composition and antigenic structure of cell walls of Corynebacterium, Mycobacterium, Nocardia, Actinomyces and Arthrobacter. J. gen. Microbiol. 28, 35.

Cummins, C. S. \& Harris, H. (1956). The chemical composition of the cell wall in some Gram-positive bacteria and its possible value as a taxonomic character. J. gen. Microbiol. 14, 583.

Cummins, C. S. \& Harris, H. (1959). Taxonomic position of Arthrobacter. Nature, Lond. 184, 831.

DA Silva, G. A. N. \& Holr, J. G. (1965). Numerical taxonomy of certain coryneform bacteria. J. Bact. 90, 921.

DAvis, G. H. G. (1955). The classification of lactobacilli from the human mouth. J. gen. Microbiol. I3, 48I.

DAvis, G. H. G. \& Freer, J. H. (1960). Studies upon an oral aerobic actinomycete. J. gen. Microbiol. 23, 163 .

DAvis, G. H. G. \& PARK, R. W. A. (I962). A taxonomic study of certain bacteria currently classified as Vibrio species. J. gen. Microbiol. 27, IOI.

FrAZIER, W. C. (1926). A method for detecting changes in gelatin due to bacteria. J. Infect. Dis. 39, 302.

GeORG, L. K. \& Brown, J. M. (1967). Rothia, gen.nov., an aerobic genus of the family Actinomycetaceae. Int. J. Syst. Bact. 17, 79.

GoopfelLow, M. (1967). Numerical taxonomy of some named bacterial cultures. Can. J. Microbiol. I3, 1365 .

GoRDON, R. E. (1966). Some strains in search of a genus-Corynebacterium, Mycobacterium, Nocardia or what? J. gen. Microbiol. 43, 329.

GoRDon, R. E. \& SMITH, M. M. (I955). Proposed group of characters for the separation of Streptomyces from Nocardia. J. Bact. 69, 147.

HARRINGTON, B. J. (1966). A numerical taxonomical study of some corynebacteria and related organisms. J. gen. Microbiol. 45, 31 .

HiLl, L. R. (1966). An index to deoxyribonucleic acid base compositions of bacterial species. J. gen. Microbiol. 44, 419.

JEFFRIEs, C. D., Holtman, D. F. \& Guse, D. G. (1957). Rapid method for determining the activity of microorganisms on nucleic acids. J. Bact. 73, 590 .

JENSEN, H. L. (1966). Some introductory remarks on the coryneform bacteria. J. appl. Bact. 29, I3.

KeDDIE, R. M., LEASK, B. G. S. \& GraINGer, J. M. (I966). A comparison of coryneform bacteria from soil and herbage: cell wall composition and nutrition. J. appl. Bact. 29, I7.

Kovacs, N. (1956). Identification of Pseudomonas pyocyanea by the oxidase reaction. Nature, Lond. 178, 703 .

lanÉEle, M.-A., Asselineau, J. \& Castelnuovo, G. (1965). Études sur les Mycobactéries et les Nocardiae. IV. Composition des lipides de Mycobacterium rhodochrous $M$. pellegrino sp., et de quelques souches de Nocardiae. Annls Inst. Pasteur, Paris 108, 69.

LAZAR, I. (1968). Serological relationships of corynebacteria. J. gen. Microbiol. 52, 77.

MATHEWS, M. M. (1966). Ultrastructure of nonphotosynthetic carotenoid-containing bacteria. $J$. Bact. 9r, 1369. 
McLean, R. A. \& Sulzbacher, W. L. (1953). Microbacterium thermosphactum, spec nov;. a nonheat resistant bacterium from fresh pork sausage. J. Bact. $65,428$.

Mossel, D. A. A. (1962). Attempt in classification of catalase-positive staphylococci and micrococci. J. Bact. 84, I 140.

Robinson, K. (I966a). Some observations on the taxonomy of the genus Microbacterium. I. Cultural and physiological reactions and heat resistance. J. appl. Bact. 29, 607.

Robinson, K. (1966b). Some observations on the taxonomy of the genus Microbacterium. II. Cellwall analysis, gel electrophoresis and serology. J. appl. Bact. 29, $6 \mathrm{I} 6$.

Runyon, E. H. (1955). Veterans Administration-National Tuberculosis Association Cooperative Study of Mycobacteria. Am. Rev. resp. Dis. 72, 866.

SIERRA, G. (1957). A simple method for the determination of lipolytic activity of microorganisms and some observations on the influence of the contact between cells and fatty substrates. Antonie van Leeuwenhoek 23, I 5.

SKerman, V. B. D. (1967). A Guide to the Identification of the Genera of Bacteria. 2nd ed. Baltimore: Williams and Wilkins.

Sokal, R. E. \& SNeath, P. H. A. (I963). Principles of Numerical Taxonomy. San Francisco: Freeman.

Splittstoesser, D. F., WeXler, M., White, J. \& Colwell, R. R. (I967). Numerical taxonomy of Gram-positive and catalase-positive rods isolated from frozen vegetables. Appl. Microbiol. 15, 158.

ThORNLEY, M. J. (1960). The differentiation of Pseudomonas from other Gram-negative bacteria on the basis of arginine metabolism. J. appl. Bact. 23, 37.

Tsukamura, M. (1966). Adansonian classification of Mycobacteria. J. gen. Microbiol. 45, 253.

Weidemann, J. F. (1965). A note on the microflora of beef muscle stored in nitrogen at $0^{\circ} \mathrm{C}$. J. appl. Bact. 28, 365 .

Willis, A. T. (I960). Lipolytic activity of some clostridia. J. Path. Bact. 8o, 379.

ZoBell, C. E. (1932). Factors influencing the reduction of nitrates and nitrites by bacteria in semisolid media. J. Bact. 24, 273. 


\section{A PPENDIX}

Table A shows the coded features and the numbers used to indicate them. Table B lists the results for these features for all the strains used.

\section{Table A}

\begin{aligned} $\begin{array}{r}\text { Feature } \\ \text { no. in }\end{array} & \\$ Table B & \\ I & \multicolumn{1}{c}{ Coded feature } \\ 2 & Colony under I mm. in diameter \\ 3 & Margin entire \\ 4 & Surface smooth \\ 5 & Consistency butyrous \\ 6 & Colony adherent \\ 7 & Colony friable \\ 8 & Colony convex \\ 9 & Colony pink \\ I0 & Colony yellow/green \\ I I & Colony yellow/red \\ I2 & Regular rod forms seen \\ 13 & Irregular rod forms seen \\ I4 & Branching rod forms seen \\ I5 & Cocci seen \\ I6 & Motile \\ I7 & Acid-fast cells present \\ I 8 & Catalase positive \\ I9 & Oxidase positive \\ 20 & Tween 20 hydrolysed \\ 21 & Tween 40 hydrolysed \\ 22 & Tween 60 hydrolysed \\ 23 & Tween 80 hydrolysed \\ 24 & Gelatin hydrolysed \\ 25 & Casein hydrolysed \\ 26 & Starch hydrolysed \\ 27 & Tyrosine hydrolysed \\ 28 & Melanin from tyrosine \\ 29 & Xanthine hydrolysed \\ 30 & Salicylate hydrolysed \\ 31 & Growth on MacConkey \\ 32 & Growth on EMB \\ 33 & Penicillin sensitive \\ 34 & Streptomycin sensitive \\ 35 & Tetracycline sensitive \\ & \end{aligned}

Feature

no. in Table B

36

37

38

39

40

4 I

42

42

43

44

45

46

47

48

49

50

52

53

54

55

56

57
58

58
59

59

60

62

63

64

65

66

67

68

69

70

\section{Coded feature}

Chloramphenicol sensitive

Novobiocin sensitive

Oleandomycin sensitive

Erythromycin sensitive

Growth on Hoyle's medium

Growth anaerobically

Growth at $5^{\circ}$

Growth at $37^{\circ}$

Cellulose hydrolysed

Aesculin hydrolysed

Arbutin hydrolysed

Glucose oxidised

Glucose fermented

Acetoin from glucose

Stern's test positive

Hippurate hydrolysed

Nitrate reduced

Nitrite reduced

Indole produced

Urea hydrolysed

Ammonia from arginine

Thornley's test positive

Citrate utilized

Gram positive

Photochromogenic

Tributyrin hydrolysed

Horse blood cleared

Neutral red test

Gluconate test

Pigment on catechol

Serum hydrolysed

DNA hydrolysed

Pigment produced

Rod forms seen

Final $\mathrm{pH}$ under $5^{\circ} \mathrm{O}$ 


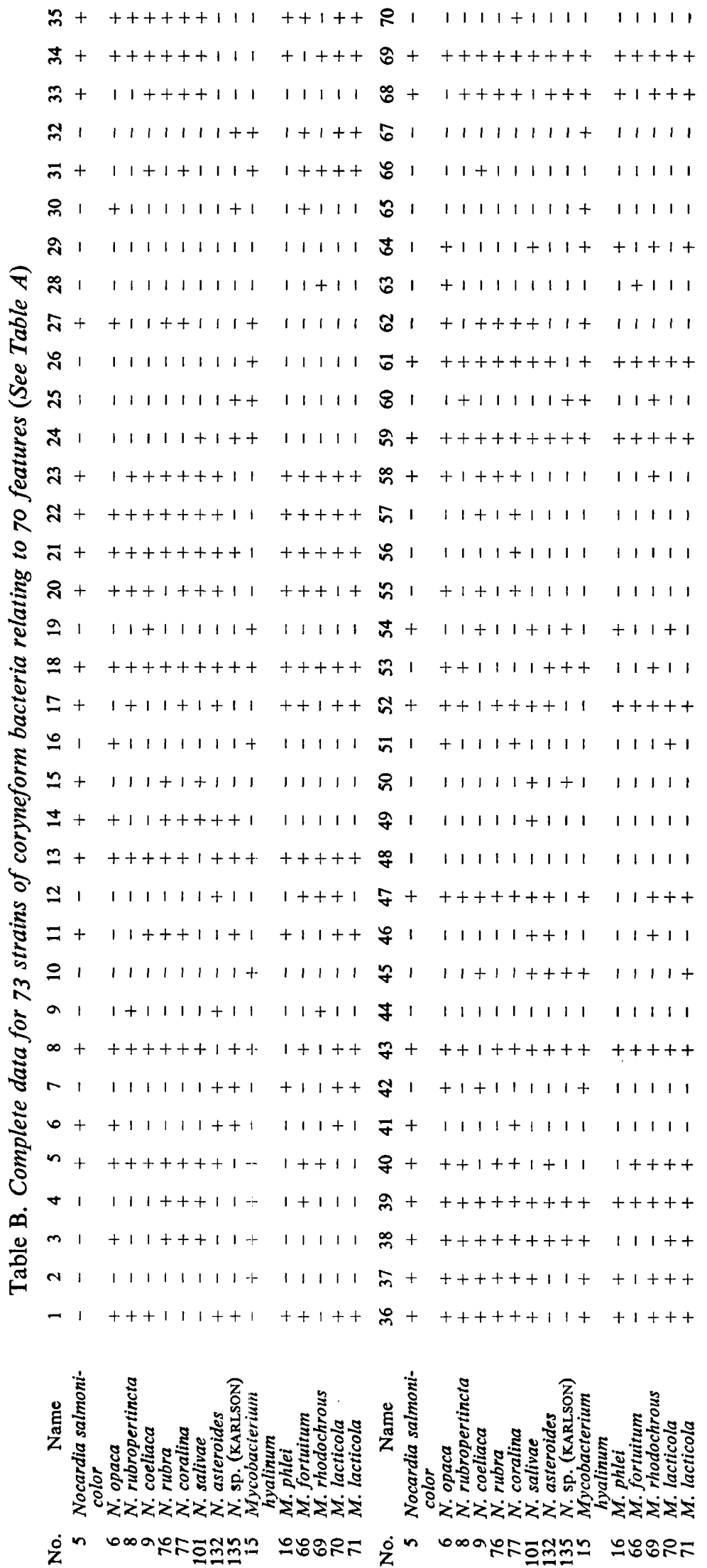


$\approx++t+1+11+++++++81+++1+11+111+++$ $\mathbf{m}++++++1+++++1 \quad 180+++111+++++++1+$ m $1+++1+1++++++++\infty+1+1+1|1| 1+1|1| 1$

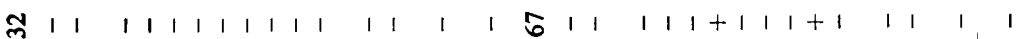

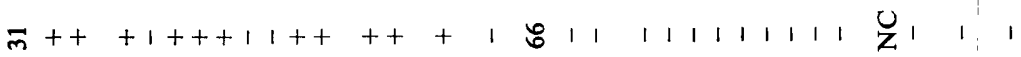

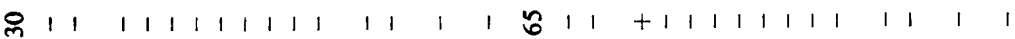

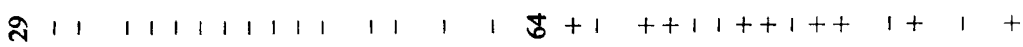

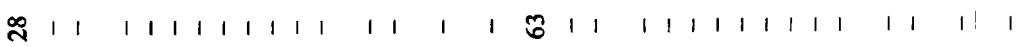

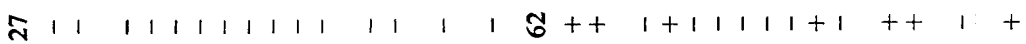
赵 $1+1+1+1++1 \quad 1 \quad 1 \quad 15+1+1++1++111+1+$

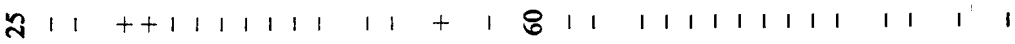

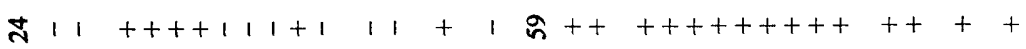

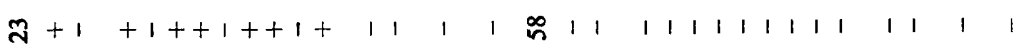

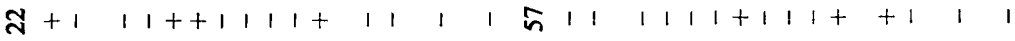
$\vec{N}+111++1111+1+1$ i $11111111111++1+1$ ㅇt+t+t+1t+11 $1+1$ 1 n $11+t+1+1+1111+1$

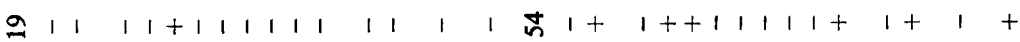
$\cong++++++++++11+++$ n $11+1+1+11++1+++$ $\approx \equiv 11111111111 \quad 11 \quad 1 \quad 1 \tilde{n}+1 \quad 11+111+11+1 \quad 1$ 过

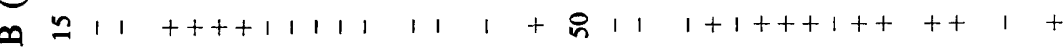

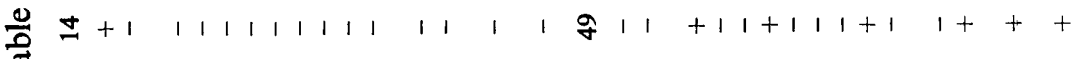
$2++11111+++1 \quad 1+1 \quad 1$ \& $11++++11+111+++$ $\simeq 11+111+111++1++F++1111111+1 \quad 1111$ $=+1 \quad 1111111111111 \quad 1 \quad 1 \quad f \quad 11 \quad 1111+1++11+++$

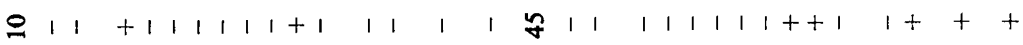

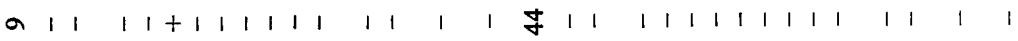
$\infty++++|1|+++1++1+\xi++++++++11+++1$ $\begin{array}{llllllllllllllllllllllllll}-1 & 1 & 1 & 1 & 1 & 1 & 1 & 1 & 1 & 1 & 1 & 1 & 1 & 1 & \mathcal{F} & 1 & 1 & 1 & 1 & 1 & 1 & 1 & 1 & 1 & 1+t+\end{array}$

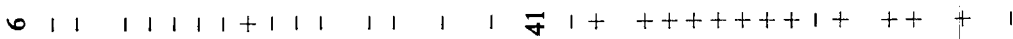
$n++++++++++++++$ \& $+1+1+++++1+1+11$ +++++++++++++ + + e $++++++++++++t$ $m \mid 1+11+11++1+11+\infty 1+++++++++++++$ N $11111+1111111+15+++1+1+++1++++$ $-++++11++++++1 \quad 1 \quad 1 \quad 20+t++++1++++++$

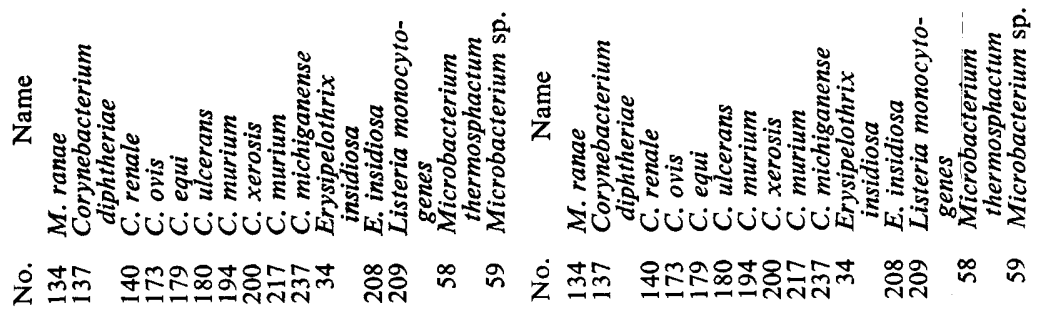




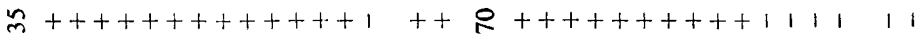

$\ddot{m}+11111111101+++++++2+++1++++++++++++$

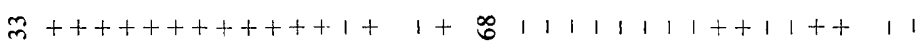

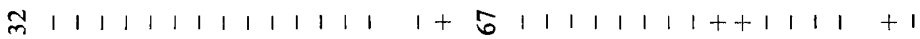

$\bar{m}+1+++++++++1+++8011111111111+111$

유 1111111111111111 1

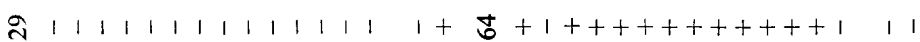

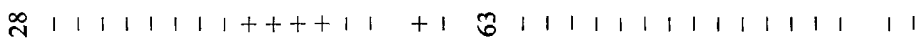

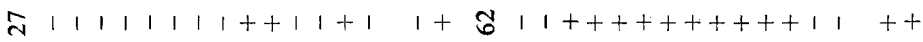

กำ1 $1111111++1111++\overrightarrow{0}+++++++1111+1+1$

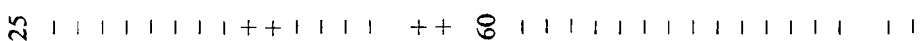

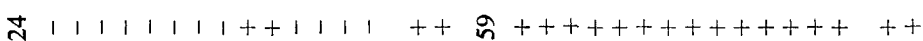

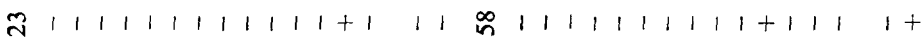

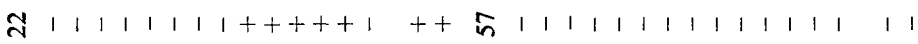

$\vec{\sim} 111111111++1++1++\infty$

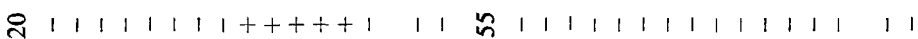

Q $111111111++++11$ 1 1 芯 $+111111+++1111111$

$\stackrel{\infty}{\infty}+1+++1+++++++++\tilde{n}++1+++++11++111+$

$\equiv|1| 1|1| 1|1| 1 \mid+1 \quad 11$ N $111111111++11+++1$

芳

$\varrho 11+1111111++11$ 1 1 ह $1111111+1|1|++++$

$\cong 111+11111111++118+1++1++111111++1$

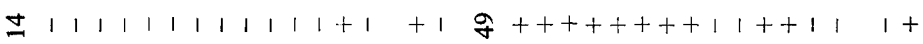

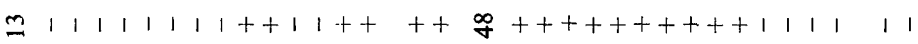

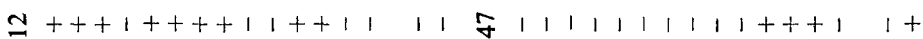

$=11111111111111118+t+++++++1111+11$

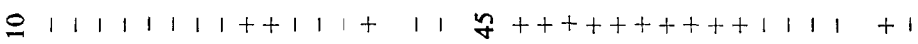

a $111111111111 \ldots 1,1181111111111111111$

$\infty+1|1| 1|1| 1|+| 1++++\mathcal{F} \mid \begin{array}{lllllllll}\mid & 1 & 1 & 1 & 1 & 1 & 1+++1+1++\end{array}$

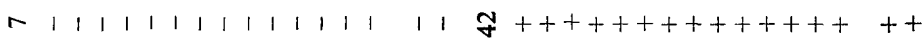

$01111111111111111111118+++++++11+111+1$

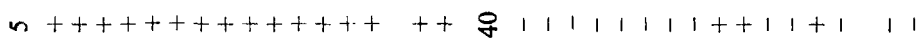

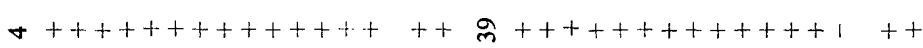

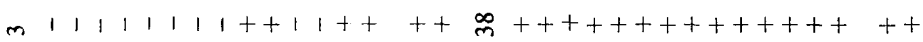

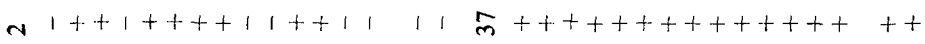

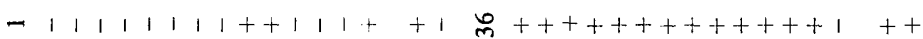

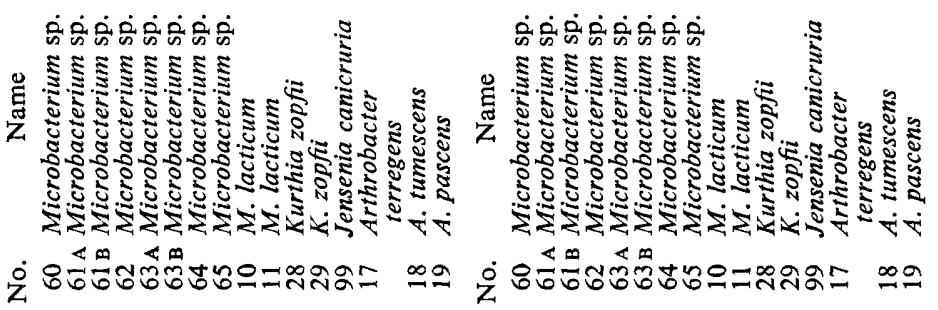


$\approx 1+t++t+1+++1+t+8+1|1| 1|+1| 1|1| 1+1$

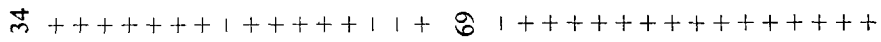

$m+t+++++1+++11+++\infty 1+1|1| 1 \mid 1++++++++$

లె $1+++++1|1| 1 \mid 1+1+\delta 1+1++11++1+1++++$

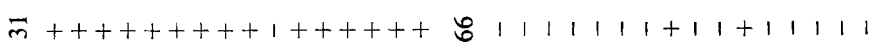

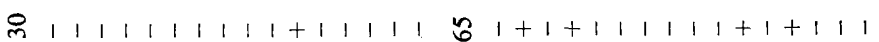

ते $11+t++1111+++1+$ t $+11+1+11++1++1+t$

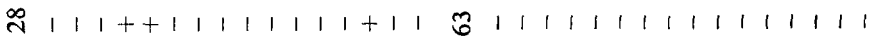

$\approx 1+t+t+t+1+t++1+\approx 0 / 1+t+1+11+t+1+$

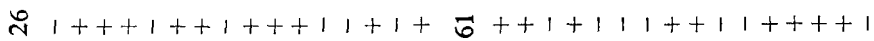

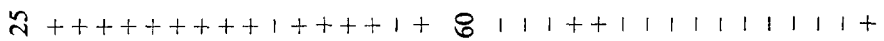

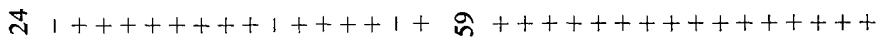

$\widehat{\Omega} 1+11111++++1++1$ 1

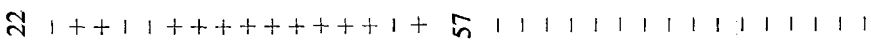

त $1++11+++++++++++\curvearrowleft \mid \cap 11+11++1+111+1+$

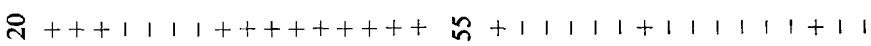

$21+t+++11+1+1++1$ \& $t+1+1|1| 1 \mid 11+1+11$

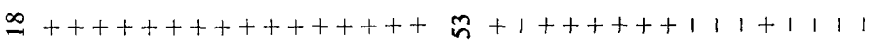

$\Xi 111111111111111111 \mathrm{~N}++1111111+1+++1++$

$\because 1+11+11++++11+1+\bar{n}+11++1+|1| 1+++11$

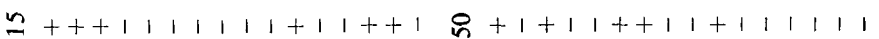

$\pm 1|1| 1+1|+1| 1|1| 1|q+1|++1|1| 1 \mid+1+1$

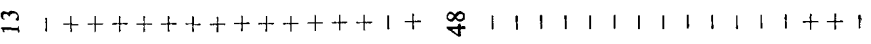

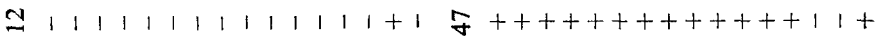

$=11111111111++1++\& 11+11++1+1111111$

$\cong 1+1|1| 1 \mid 1+++11+11 \% 1++++++++++11+1+$

$0111111111111111111 \% 111111111111111111$

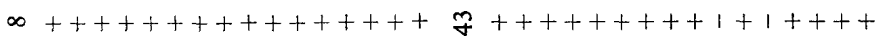

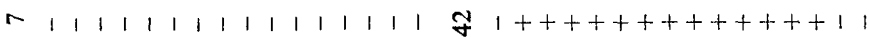

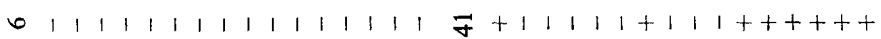

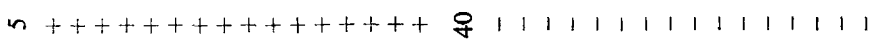

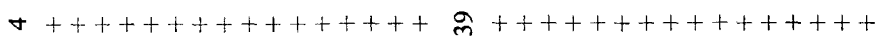

$m+++++++++++++++\infty)+++++++++++++++$

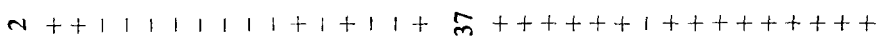

$-1|1| 1+t \mid 1+1+1111000+t+t+t+t+t+t+t$

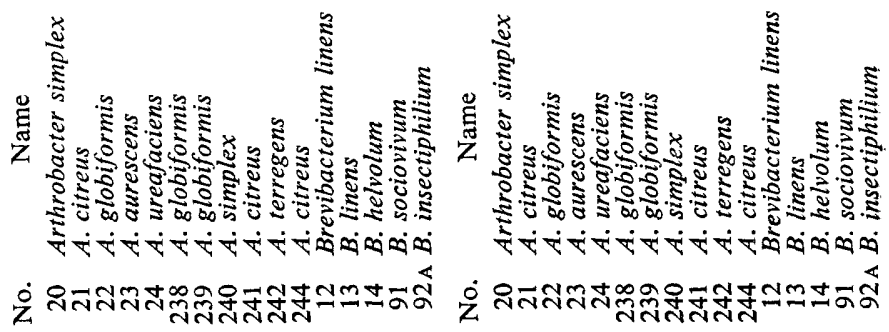



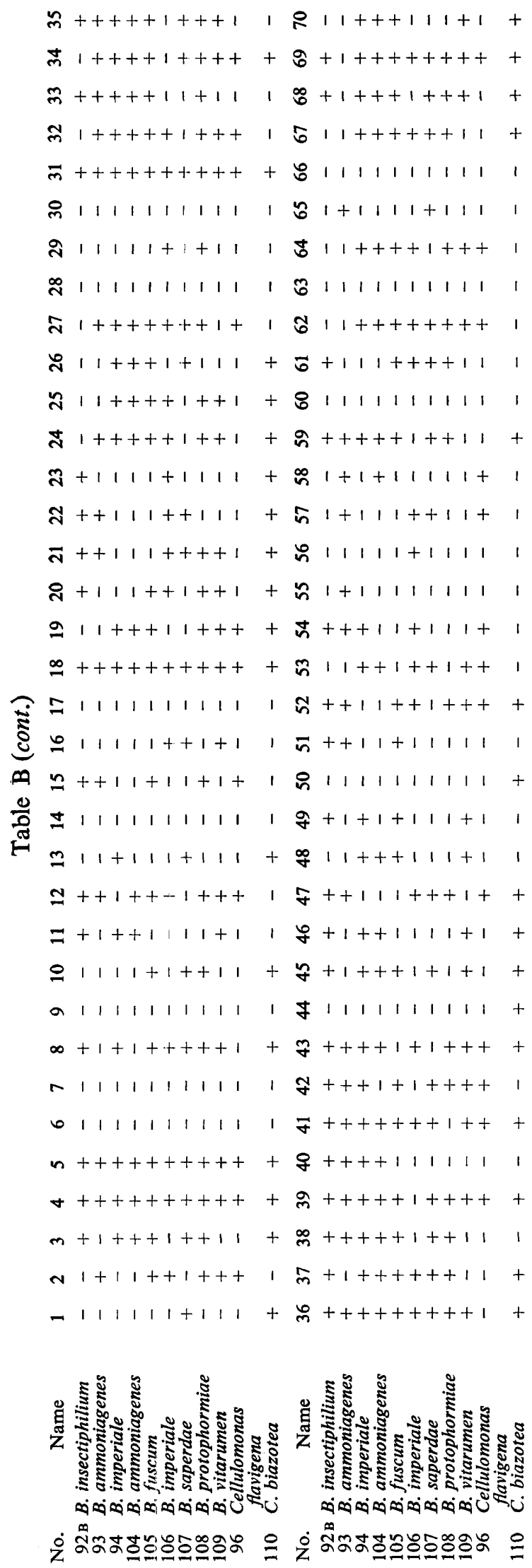